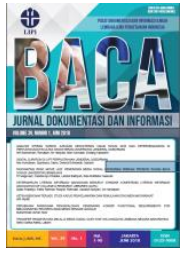

\title{
PEMANFAATAN INTERNET UNTUK PENGHIDUPAN DI KALANGAN PEMUDA PEDESAAN
}

\author{
Pawit M. Yusup ${ }^{1 *}$, Neneng Komariah ${ }^{2}$, Nurmaya Prahatmaja ${ }^{3}$, \\ Samson $\mathrm{CMS}^{4}$ \\ 1,2,3,4 Universitas Padjadjaran \\ *Korespondensi: pawitmy@gmail.com
}

Diajukan: 25-02-2019; Direview: 01-04-2019; Diterima: 16-05-2019; Direvisi: 04-10-2019

\begin{abstract}
This study aims to examine more deeply about the use of the internet for entrepreneurial purposes or livelihoods among rural youth. The method used is observation and in-depth interviews with 20 business informants in this internet sector. The results of the study illustrate that (a) viewed from the aspect of knowledge, business people understand correctly that the internet is the main media used to find information and sources of livelihood information; (b) viewed from the aspect of motivation, they are encouraged to use the internet for entrepreneurship because it is very easy to learn; (c) judging from the aspects of behavior and experience, business people in this sector feel very disturbed when there are a network disorder.
\end{abstract}

\begin{abstract}
ABSTRAK
Penelitian ini bertujuan mengkaji lebih dalam mengenai pemanfaatan internet untuk tujuan wirausaha atau penghidupan di kalangan pemuda pedesaan. Metode yang digunakan adalah observasi dan wawancara mendalam terhadap 20 orang informan pelaku usaha di sektor internet. Hasil penelitian menunjukkan bahwa (a) dilihat dari aspek pengetahuan, para pelaku usaha memahami benar bahwa internet menjadi media utama yang digunakan untuk mencari informasi dan sumber informasi penghidupan; (b) dilihat dari aspek motivasi, mereka terdorong menggunakan internet untuk berwirausaha karena sangat mudah dipelajari; (c) dilihat dari aspek perilaku dan pengalaman, para pelaku usaha di sektor ini, merasa amat terganggu manakala terjadi gangguan listrik dan jaringan internet.
\end{abstract}

Keywords: Internet; Village youth; Information resources; Businessman; Livelihood

\section{PENDAHULUAN}

Internet sudah dikenal sejak lama, bahkan saat ini hampir semua sektor kehidupan manusia sudah terkait dengan internet. KBBI (2017) mendefinisikan internet sebagai "jaringan komunikasi elektronik yang menghubungkan jaringan komputer dan fasilitas komputer yang terorganisasi di seluruh dunia melalui telepon atau satelit”. Internet sebagai global computer network dapat menghubungkan jaringan komputer yang satu dengan sistem jaringan komputer lain di seluruh dunia dengan menggunakan satelit dan telepon, juga menghubungkan pengguna komputer dengan sistem jaringan layanan, seperti e-mail, chat room, dan world wide web.

Di Indonesia, internet sudah masuk ke hampir seluruh pelosok desa. Semua sektor kehidupan manusia saat ini hampir dapat dipastikan terkait dengan internet. Pada sektor ekonomi, politik, sosial, budaya, agama, dan pendidikan, internet sudah digunakan untuk fasilitasi kegiatannya. Di lingkungan keluarga, internet sudah banyak digunakan untuk berbagai kegiatan, termasuk untuk fasilitasi penghidupan mereka. Mereka menggunakan internet untuk kepentingan pendidikan, komunikasi, sosial, bisnis, dan lainnya. 
Dilihat dari sisi penggunanya, internet sudah digunakan oleh berbagai kalangan. Para pengelola media, pengelola media massa, penerbit buku, dosen, guru, pustakawan, pedagang, sektor pemasaran, dan gamers, semuanya menggunakan internet. Alasan penggunaannya beragam sesuai dengan kepentingan dan kemanfaatannya. Mereka menggunakan internet dengan tujuan untuk berkomunikasi, fasilitasi pekerjaan, hingga untuk kepentingan mengakses data dan informasi. Mereka mencari dan menggunakan informasi dari sumber internet. Bukan hanya orang kota, orang yang hidupnya di desa pun ternyata banyak yang mengandalkan penghidupannya dari aplikasi internet (Abdi \& Rachman, 2017).

Menurut APJII (Asosiasi Penyelenggara Jasa Internet Indonesia), pada tahun 2016, pengguna internet di Indonesia berjumlah sekitar 132,7 juta pengguna $(51,5 \%)$ dari total penduduk Indonesia yang jumlahnya sekitar 256,2 juta jiwa. Dari jumlah itu, pengguna terbanyak berada di Jawa, yakni sekitar 86.339 .350 pengguna (65\%). Jumlah ini menunjukkan kecenderungan meningkat secara tajam jika dibandingkan dengan jumlah pengguna internet pada tahun-tahun sebelumnya. Pratama (2017) mengemukakan bahwa pertumbuhan jumlah pengguna internet terbesar di dunia adalah Indonesia. Sekitar 69\% rakyat Indonesia menggunakan internet melalui perangkat mobile, selebihnya melalui komputer desktop dan tablet.

Berdasarkan uraian di atas dan hasil pengamatan langsung ke beberapa desa di Jawa Barat bagian Selatan dalam beberapa tahun terakhir, diperoleh keterangan tentang adanya sejumlah penduduk berusia muda di pedesaan yang tergabung dalam kelompok kegiatan usaha berbasis fasilitas internet. Mereka melakukan kegiatan usahanya melalui pemanfaatan jaringan internet dan beragam media sosial, seperti Facebook, Youtube, dan Aplikasi lainnya. Ada di antara mereka yang menjual barang dagangannya melalui Youtube, Facebook, Instagram, dan media sosial lainnya. Mereka berbisnis menggunakan fasilitas internet secara kelompok dan atau perorangan. Dilihat dari segi usia, para pelaku usaha di sektor internet sekitar usia 16-40 tahun. Mereka bahkan ada yang rela meninggalkan pekerjaan sebelumnya dan beralih ke jenis usaha yang menggunakan internet sebagai fasilitas kegiatannya. Di antara mereka ada yang berhasil dengan mendapatkan penghasilan yang cukup untuk memenuhi kebutuhan diri dan keluarganya.

Penelitian ini mengkaji tentang bagaimana internet digunakan para pemuda pedesaan dalam penghidupan mereka, yang diketahui dari berbagai pengalaman mereka dalam memanfaatkan internet untuk berwirausaha. Pengalaman ini meliputi aspek pengetahuan, aspek motivasi, dan aspek perilaku dan pengalaman dalam menjalani penghidupan di sektor internet.

\section{TINJAUAN PUSTAKA}

\subsection{Internet}

Internet tercipta pada tahun 1969 dengan lahirnya Arpanet, suatu proyek eksperimen Kementrian Pertahanan Amerika Serikat bernama DARPA (Departement of Defense Advanced Research Project Agency). Lembaga tersebut membawa misi untuk mencoba menggali teknologi jaringan untuk menghubungkan para peneliti dengan berbagai sumber daya, seperti komputer dan pangkalan data yang besar. Arpanet berhasil membangun jaringan tersebut dan berkembang hingga sekarang. Arpanet mencakup puluhan bahkan ratusan juta orang dan sistem jaringan (Ardianto \& Erdinaya, 2007).

Reddick \& King (1996), mendefinisikan internet sebagai suatu istilah yang digunakan untuk menggambarkan saling hubungan antar jaringan-jaringan komputer, sehingga 
memungkinkan komputer-komputer itu saling berkomunikasi satu sama lain. Bukan hanya orang yang berkomunikasi dengan orang, melainkan juga bisa orang dengan mesin, dan bahkan mesin dengan mesin.

NUA Survey memperkirakan bahwa jumlah pengguna internet pada Februari 1999 telah mencapai 153,5 juta, dan pada awal 2000 berada pada angka 248,6 juta pengguna. Artinya, pada waktu itu terjadi pertumbuhan sebanyak 95,1 juta pengguna baru. Sebulan kemudian bertambah menjadi 275,54 juta pengguna (Febrian, 2002). Perkembangan internet terjadi luar biasa, dalam beberapa dekade pertumbuhannya menjadi sangat cepat.

Pengguna internet di Indonesia pada tahun 2014 diprediksi sudah melewati angka 85 juta. Hal tersebut merupakan jumlah pengguna internet yang sangat besar. Menurut APJII, tahun 2015 menjadi tonggak sejarah bagi perkembangan dunia internet di Indonesia. Pada tahun ini, pengguna internet Indonesia menembus 100 juta lebih (APJII, 2016). Pada tahun 2016, jumlah pengguna internet di Indonesia sudah mencapai 132,7 juta. Artinya, lebih dari setengah penduduk Indonesia itu pengguna internet (APJII, 2016), sedangkan pada tahun 2017 meningkat menjadi 143,26 juta jiwa (APJII, 2017).

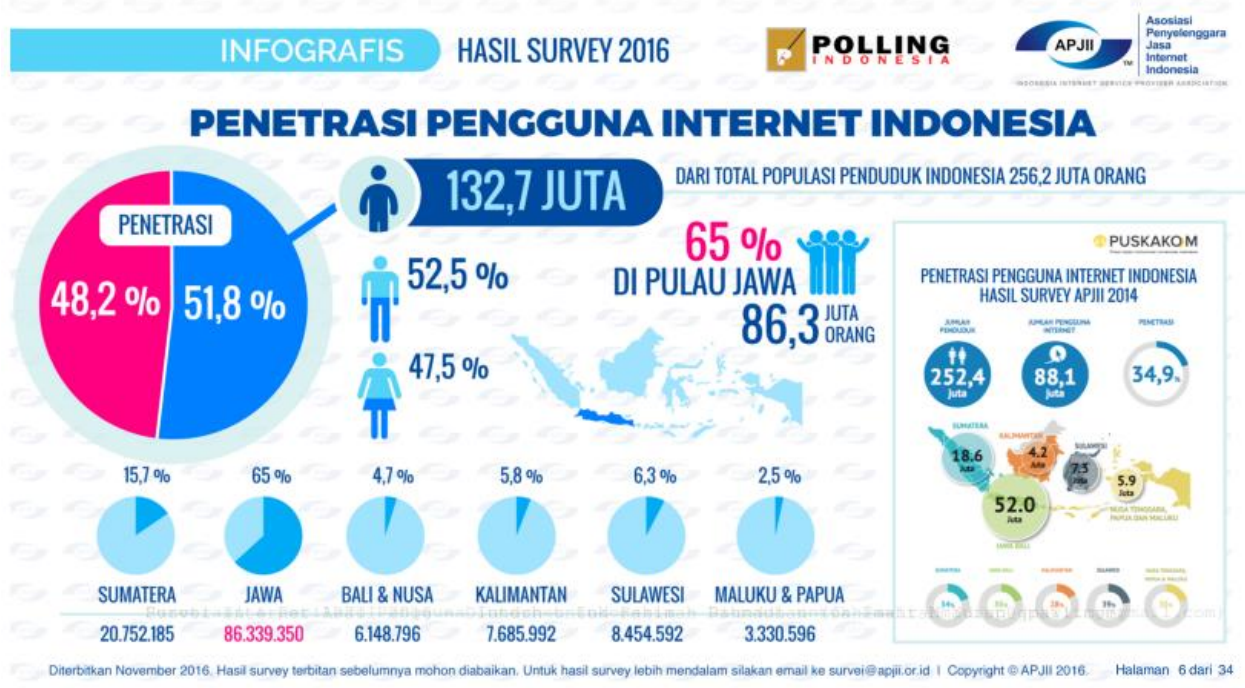

Gambar 1. Jumlah pengguna internet Indonesia (APJII, 2016)

$$
\mathrm{Z}
$$

Berdasarkan karakteristik komputer dan internet, perorangan ataupun secara kelompok dapat bekerja tanpa dibatasi oleh tempat dan waktu. Kapan saja dan di mana saja orang bisa menjalankan pekerjaannya. Di rumah, di perjalanan kereta api, di terminal, di rumah makan saat santai, bahkan di malam hari ketika sebagian besar orang lain sedang tidur, seseorang bisa bekerja dengan komputer dan internet (Onlenpedia.com. 2017).

\subsection{Pasar Bebas ASEAN}

Sejak diberlakukannya pasar bebas ASEAN pada Januari 2016, secara praktis tidak ada lagi halangan bagi negara dan masyarakat yang ada di lingkup ASEAN untuk berbisnis secara antar negara dan bahkan individu. Setiap orang bebas melakukan perdagangan, bekerja, dan bertransaksi dengan orang lain dalam lingkungan negara ASEAN. Istilah yang menggambarkan kondisi tersebut dikenal sebagai MEA (Masyarakat Ekonomi ASEAN) atau 
AEC (ASEAN Economic Community). Salah satu tujuan MEA yaitu untuk membuka kesempatan bagi negara-negara ASEAN agar lebih kompetitif dalam meningkatkan pertumbuhan ekonomi di negara-negara ASEAN. Setiap orang dapat membuka usaha di bidang apa saja dengan pasar yang lebih luas. Beberapa jenis usaha yang mungkin lebih banyak dicari dan dikembangkan antara lain adalah jenis UMKM (Usaha Mikro, Kecil, dan Menengah), bisnis Investasi, sektor pendidikan, jenis usaha kreatif, bisnis online, dan pariwisata. Jenis usaha rumahan yang dipasarkan secara online pun di era digital dan internet dapat berkembang dengan pesat. Konteks memasarkan secara online dalam hal ini mengandung implikasi keharusan para pelakunya menguasai komputer dan sistem jaringan internet. Setidaknya, seseorang yang melakukan bisnis secara online, harus memiliki atau menguasai aplikasi komputer dan internet, serta perangkat aplikasi dasarnya (Pujiani, 2014).

\section{METODE}

Metode penelitian yang digunakan adalah observasi dan wawancara mendalam terhadap 15 orang yang tergolong penduduk dari keluarga prasejahtera di Jawa Barat Bagian Selatan, khususnya di beberapa desa di Kecamatan Pamarican Kabupaten Ciamis. Observasi dilakukan dengan memperhatikan keberadaan sosio-ekonomi penduduk dan profil desa di lokasi penelitian. Kegiatan penelitian berlangsung pada tahun 2017 dan 2018. Pengumpulan data dilakukan dengan cara: (1) mendeskripsikan peristiwa yang sedang berlangsung; (2) mencatat peristiwa yang telah berlangsung; (3) menganalisis ide-ide yang muncul dengan memperkaya inferensi; (4) mencatat kesan-kesan dan perasaan orang-perorangan; dan (5) membuat catatan untuk informasi lebih lanjut (Bailey, 1987). Penelitian lapangan dilakukan dengan cara mengamati, mendengar, bertanya, mencatat, dan mendeskripsikan peristiwa yang sedang terjadi sesuai dengan tema penelitian. Tema yang diteliti fokus pada aspek pemanfaatan internet untuk penghidupan bagi para pemuda, yang mencakup aspek pengetahuan, motivasi, perilaku, dan pengalaman dalam menjalani penghidupan menggunakan internet.

Langkah berikutnya adalah menyusun proposisi atau konstruk derajat kedua dari hasil pengamatan langsung ke lapangan. Penyusunan proposisi ini didasarkan pada hasil analisis data yang sudah terkategorisasi. Berdasarkan perspektif outcomes pengamatan di lapangan, pengetahuan yang dirumuskannya bersifat hipotetik yang dibangun berdasarkan pola hubungan tertentu antar aspek dalam situasi dan realitas sosial. Pada tataran praktik, peneliti mencoba membangun hipotesis kerja, atau setidaknya menyusun proposisi yang digunakan untuk memahami konteks dan waktu, yang dalam konteks tertentu dikenal dengan istilah konstruk derajat kedua menurut pandangan Schutz (1967) dan Mulyana (2002). Praktik ini semacam kerangka teoretis yang dibangun berdasarkan data hasil penelitian lapangan. Hasilnya bukan sekadar narasi hasil pengamatan informan di lapangan, tetapi mengarah pada bentuk-bentuk proposisi dan temuan penelitian yang bermanfaat bagi perkembangan pengetahuan selanjutnya.

\section{HASIL DAN PEMBAHASAN}

\subsection{Menggunakan Informasi Internet}

Istilah informasi sudah sangat dikenal oleh masyarakat. Hampir semua bidang ilmu pengetahuan menggunakan istilah informasi sesuai dengan konteksnya. Makna informasi bersifat multiperspektif, multidimensional, multitafsir, dan multipenggunaan. Konsepsinya pun beragam sesuai dengan beragamnya aspek kehidupan manusia. Salah satu konteksnya yang melibatkan informasi pada aspek kegiatan dan kehidupan manusia adalah perilaku 
informasi (Wilson, 2000; Wilson, 2002). Konsep perilaku informasi memiliki dimensi yang berbeda dalam penekanannya, yakni dimensi perilaku pencarian atau penemuan informasi dan dimensi perilaku penggunaan informasi (Thivant, 2005).

Dalam konteks seperti ini, perilaku informasi dimaknai sebagai keseluruhan pola laku atau tindakan manusia terkait dengan informasi dan aspek-aspeknya. Selama tindakan manusia memerlukan, memikirkan, memperlakukan, mencari, membagi, memilah, dan menggunakan informasi yang berasal dari berbagai sumber, media, dan saluran, termasuk saluran komunikasi tatap muka, komunikasi antar pribadi, komunikasi kelompok, juga termasuk ke dalam konsep perilaku informasi. Dalam konteks tersebut, sebagai contoh, misalnya, orang yang menonton siaran televisi, menonton acara hiburan, mendengarkan siaran radio, menyimak pidato dari seseorang, membaca beragam bahan bacaan yang tersedia di media cetak dan elektronik, dan membaca media sosial. Dengan melihat konteks perilaku informasi bisa dibayangkan bahwa setiap orang pada dasarnya adalah pencari, pengguna, dan penerima informasi yang berasal dari berbagai sumber dan saluran.

Pustaka lain yang menjelaskan konsep perilaku informasi berasal dari Johnstone et al. (2004) yang mengatakan bahwa perilaku informasi dipandang sebagai "how individuals approach and handle information. This includes searching for it, using it, modifying it, sharing it, hoarding it, even ignoring it" (bagaimana seseorang mendekati dan menangani informasi, di sini termasuk bagaimana mencari, menggunakan, mengubah, membagi, menyimpan, bahkan mengabaikanya). Perilaku informasi dapat berkonteks sempit dan luas, tergantung pada lingkup dan sudut pandang pembahasannya. Tidak ada batasan perilaku informasi yang komprehensif dan berlaku untuk semua aspek. Informasi hampir selalu mengandung konteks yang spesifik, seperti contohnya informasi kesehatan (Yusup \& Komariah, 2014), informasi lingkungan, informasi penghidupan, dan sebagainya.

Dalam kajian ilmu perpustakaan dan informasi, perilaku informasi bermakna sebagai bagian dari bidang penelitian dan pengembangan. "Information behavior, is a subdiscipline within the field of library and information science. It describes how people need, seek, manage, give and use information in different contexts" (Savolainen, 2007; Fisher, 2008). Perilaku informasi merupakan suatu subdisiplin di dalam ilmu informasi dan perpustakaan yang menjelaskan bagaimana orang membutuhkan, mencari, mengelola, memberi, dan menggunakan informasi dalam beragam konteks. Beberapa konteksnya antara lain: perilaku mencari informasi (information-seeking behavior) dan perilaku informasi pada praktik kehidupan sosial manusia (human information behavior). Konteks tersebut menggambarkan bahwa perilaku informasi dimaknai sebagai segala tindakan atau perilaku manusia dalam bentuk upaya untuk menemukan makna dari konteks sosialnya. Konsepsi seperti itu pernah ditegaskan oleh Kuhlthau bahwa information seeking as a process of seeking meaning (Limberg, 1999; Grešková, 2007). Konsepsi perilaku informasi mengandung makna pola laku pencarian dan pola laku penggunaan informasi dalam berbagai konteks sosial. Thivant (2005) menyebutnya sebagai information seeking and use behavior, yang artinya penemuan dan penggunaan informasi. Maka informasi yang dicari, ditemukan, dan digunakannya mengandung konteks informasi untuk penghidupan.

Dengan menggunakan konsepsi information seeking as a process of seeking meaning (pencarian atau penemuan informasi dipandang sebagai proses pencarian makna) (Limberg, 1999; Grešková, 2007), setiap dimensi realitas praktik sosial yang disentuhnya akan menjadi bagian yang melekat dengan realitas sosial yang dimaknai atau ditemukan. Konsepsi mencari atau menemukan informasi penghidupan, dimaknai sebagai proses menemukan makna 
penghidupan. Konsepsi mencari informasi pekerjaan spesifik yang dapat diartikan sebagai proses mencari atau menemukan pekerjaan spesifik. Sebagai contoh, seseorang bertanya kepada tetangga dekat yang sudah berpengalaman berdagang di pasar, tentang jenis barang apa saja yang yang biasanya laku dijual, atau bertanya tentang barang apa saja yang masih belum banyak dijual di pasar tradisional. Orang tersebut berposisi sebagai pencari dan pengguna informasi tentang barang yang banyak dijual dan laku di pasar. Ketika orang itu mencari informasi ke tetangga dekat, dia memiliki konteks berfikir, bertujuan, motivasi, alasan, harapan, dan keterangan lain tentang berjualan di pasar, atau berusaha mencari penghidupan di pasar. Aspek-aspek ini melekat dengan tindakan mereka yang sedang melakukan usaha dengan internet.

\subsection{Dari Bukan Segalanya Menjadi Segalanya}

Sekitar satu dekade yang lalu, pengguna internet di Indonesia sekitar 20 juta, namun pada tahun 2016 jumlahnya sudah mencapai 132,7 juta lebih (Gambar 1). Pada tahun 2017 jumlahnya meningkat menjadi 143, 26 juta jiwa (APJII, 2017). Hal ini menggambarkan bahwa masyarakat sudah menganggap internet sebagai bagian dari kehidupan kesehariannya. Masyarakat pada masa satu dekade yang lalu masih menganggap internet bukan segalanya. Para pencari dan pengguna informasi masih banyak yang memanfaatkan sumber lain yang berbasis cetak, sumber orang, dan sumber lainnya. Hal ini sangat berbeda jika dibandingkan dengan masa sekarang, yang tidak terpisah dari internet dan aplikasi penggunaannya.

Hasil pengamatan penulis yang didukung oleh berbagai sumber online, terutama pada kurun waktu satu sampai dua dekade menunjukkan bahwa pemanfaatan internet dapat digambarkan sebagai berikut.

1) Internet sebagai media komunikasi banyak sekali manfaatnya, bahkan untuk bidang tertentu bersifat mutlak penggunannya. Sedangkan pada bidang lainnya, internet masih dianggap sebagai pendamping atau pelengkap. Ada beberapa manfaat internet dalam kehidupan masyarakat, khususnya yang terkait dengan bidang penghidupan manusia, seperti berjualan barang dan jasa, transaksi online, pendidikan dan pembelajaran, pengembangan diri, dan kewirausahaan.

2) Sampai tahun 2019 sudah ada triliunan halaman web, dan tentu saja orang tidak mungkin membaca kontennya secara keseluruhan. Dari jumlah informasi sebanyak itu, hanya sebagian kecil saja yang gratis. Sebagai contoh, tidak semua jurnal dan tulisan ilmiah lain yang bermutu ada di internet. Sementara itu, buku teks dan buku ilmiah lebih sedikit yang online dan diedarkan secara gratis. Tidak mungkin semua informasi dan sumber-sumber informasi yang dibutuhkan masyarakat tersedia di internet. Meskipun mesin pencari informasi yang ditampilkan di internet jumlahnya cukup banyak, seperti Google, Yahoo, Infoseek, MSN, dan lainnya, namun pengguna internet belum tentu menggunakan semua browser tersebut. Sebagai contoh, dalam praktek, terkadang orang mengalami kegagalan dalam menggunakan mesin pencari ketika menelusur informasi yang diinginkannya; akibatnya ia tidak bisa menemukan informasi yang dicari. Kondisi seperti ini dimungkinkan karena faktor mesin yang bermasalah dan faktor teknis lainnya, atau informasi yang dicari sudah tidak ada lagi di web karena sudah dihapus. Selain itu, masalah lain yang cukup mengganggu pencari informasi di internet adalah adanya tampilan iklan yang muncul di layar monitor, sehingga cukup mengganggu pengguna internet yang sedang tidak tertarik dengan iklan tersebut. Contoh lain seperti artikel ilmiah yang dipublikasikan melalui sistem OJS (Online Journal System) yang 
diselenggarakan oleh berbagai lembaga ilmiah nasional dan internasional yang kredibel dan dapat diakses secara gratis, membuat Indonesia menargetkan tertinggi di ASEAN dalam penerbitan artikel pada jurnal (Risbang Dikti, 2019).

3) Dilihat dari sisi konten, pada umumnya tulisan di web sudah diubah menjadi tampilan yang serba ringkas karena tempatnya yang terbatas. Informasi yang banyak seperti ini biasanya di-update secara tidak jelas frekuensinya, ada yang harian, mingguan, atau bulanan, atau terkadang tidak pernah di-update sampai halaman web-nya berhenti sendiri. Sebagai contoh, ketika orang sedang mencari informasi tentang subjek ilmu pengetahuan yang lebih spesifik, selain yang dicari sering tidak sesuai dengan kebutuhan, juga sering muncul subjek-subjek lain yang jumlahnya banyak sekali dan sebagian besar tidak relevan dengan subjek yang dibutuhkan. Subjek-subjek yang bermunculan tadi bahkan sering menarik perhatian orang untuk membukanya. Setelah dibuka, ternyata bukan itu yang mereka cari. Akhirnya pencari informasi tersesat jalan, waktu habis terbuang percuma namun tidak mendapatkan informasi yang dicari. Intinya, sangat sulit melakukan kontrol atas informasi yang ada di web, baik kontrol dalam pengertian mengendalikan pencariannya, ataupun kontrol terhadap kualitas informasinya. Sebagai contoh, orang akan mencari informasi mengenai 'peranan seks dalam perkawinan', ketika rangkaian kata tersebut diketikkan dalam browser Google, muncul dalam tampilan web yang jauh dari harapan, seperti informasi pornografi dan freesex. Hal ini juga terjadi pada situs jurnal yang berbasis online dalam beberapa tahun ini, informasi dan sumber-sumber informasi yang bersifat ilmiah pun semakin banyak dan semakin mudah dicari. Misalnya pada 8 Mei 2018, publikasi ilmiah internasional Indonesia berjumlah 8.269 jurnal, jumla tersebut melampaui Singapura yang jumlahnya sekitar 6.825 (Risbang Dikti, 2019).

4) Pada masa sekarang, orang dapat mengakses banyak sekali jurnal ilmiah yang sebagian besar dapat digunakan untuk memenuhi kebutuhan informasi, termasuk informasi penghidupan. Sekarang adalah era baru publikasi jurnal di Indonesia, semua orang memiliki kesempatan luas dalam mengakses informasi sesuai dengan kebutuhannya (Irawan; Erwin, dkk, 2018). Semua informan penelitian ini menggunakan sumber-sumber informasi dari internet untuk mendukung usahanya. Mereka menjual barang dan jasa melalui Facebook, Youtube, dan media sosial lainnya (hasil observasi dan diskusi dengan informan 2017).

5) Terkait dengan pengalaman ketika seseorang sedang dikejar waktu untuk segera menyelesaikan sebuah tulisan yang akan dipresentasikan besok hari, dan ia mengandalkan informasi yang ada di internet. Dalam pencarian informasi di internet sering terjadi laman yang dibuka sibuk, padat, dan atau gagal dibuka. Akhirnya informasi yang dicari tidak ketemu. Selain itu, tema dan judul jurnal elektronik terkadang sering berubah tanpa pemberitahuan, padahal banyak orang yang masih membutuhkan judul atau tema terdahulu. Banyak sumber dari internet yang berkualitas, seperti contohnya informasi dari sumber jurnal online dan buku elektronik. Jumlah e-book sekarang jumlahnya pun semakin banyak dan semakin mudah diakses dengan biaya relatif murah. (APJII, 2016; 2017). Sekarang jurnal online semakin banyak dan setiap orang bisa mengaksesnya tanpa harus membayar (Risbang Dikti, 2019; Irawan, Erwin, dkk, 2018).

6) Sumber-sumber informasi seperti buku dan tulisan yang baru terbit, sekarang banyak yang disediakan di internet dan diakses secara gratis. Dengan semakin banyaknya penduduk yang lahir dan dibesarkan di era digital, pola membaca dan menggunakan bahan bacaan berubah. Anak-anak sekarang lebih tahan membaca berlama-lama di depan 
komputer dibandingkan dengan orang tuanya. Indo Telko (2018) menyatakan bahwa "sebanyak 91\% generasi muda Indonesia menyatakan bahwa internet semakin mendorong mereka memiliki semangat wirausaha dan $83 \%$ berniat atau sudah mendirikan bisnis online". Para pelaku usaha di sektor internet, termasuk para pemuda di pedesaan termotivasi untuk terus berkreasi dan berwirausaha dengan memanfaatkan internet, meskipun mereka hidup di pedesaan (hasil observasi 2017).

7) Dilihat dari sektor lembaga publik, terlihat bahwa ternyata belum semua layanan publik menggunakan internet. Di perpustakaan umum, perpustakaan sekolah (dari tingkat dasar sampai menengah dan atas), lembaga arsip, museum, dan lembaga layanan publik sejenis, masih ada layanan konvensional. Khusus untuk jenis perpustakaan umum, tidak mungkin mampu menjangkau semua lapisan masyarakat melalui layanan internet. APJII (2018) mengemukakan bahwa penetrasi internet di Indonesia mencapai lebih dari 143 juta jiwa. Ini artinya masih ada sekitar kurang dari lima puluh persen penduduk Indonesia tidak menggunakan internet. Wilayah pedesaan di Indonesia pun belum semuanya terjangkau internet. Dilihat dari sisi masyarakatnya, belum semua anggota masyarakat memiliki kemampuan mengakses internet. Selain secara teknis sangat sulit dan akan menghilangkan keutuhan informasi yang disajikan pada jenis koleksi konvensional, internet juga memiliki berbagai keterbatasan. Masyarakat masih membutuhkan ketua RT, ketua RW, dan Kepala Desa ketika berurusan dengan masalah administrasi kependudukan. Orang pun masih membutuhkan kehadiran orang lain secara fisik dalam masyarakat. Dalam konteks ini, internet tidak bisa digunakan untuk semua aspek kehidupan, termasuk untuk mendukung penghidupan. Meskipun demikian, perkembangan penggunaan internet ke depan juga dapat menentukan kehidupan masyarakat. Transaksi bisnis dan keuangan secara online sekarang sangat dikenal oleh masyarakat, baik di kota maupun di desa (nextren.grid.id, 2018). Sebagian besar kalangan muda di desa, sudah menggunakan sistem transaksi online dalam beberapa urusan (hasil observasi 2018).

8) Jika dilihat dari sisi konten dari sumber-sumber informasi berbasis internet. Meskipun jaringannya semakin luas dan mampu menampung informasi dan sumber-sumber informasi yang tak terbatas jumlahnya, namun banyak informasi yang tak berguna (sampah). Sebelum tahun 2000-an, jarang sekali informasi yang berkualitas seperti jurnal ilmiah. Namun sekarang, e-journal dan e-book sudah mulai banyak yang dipublikasikan di internet dan gratis (Irawan, Erwin, dkk., 2018).

9) Seiring dengan perkembangan teknologi informasi dan komunikasi, internet menjadi bagian yang tidak dapat terpisah dari kehidupan masyarakat. Di bidang usaha bisnis, tanpa adanya internet, orang dapat kehilangan peluang usaha karena terkait kehidupan mereka (hasil observasi 2017 dan 2018).

10) Untuk saat sekarang, menggunakan internet relatif mudah. Ada beberapa pertimbangan penggunaan internet untuk penghidupan masyarakat, diantaranya kecepatan, ketepatan, kapasitas ruang yang besar, adanya kerahasiaan data milik pribadi, efisien, efektif. Pertimbangan lainnya yaitu aspek kemudahan berinteraksi dan berkomunikasi, keluasan lingkup pergaulan, kemampuan mengolah data dalam jumlah besar, jaringan global, sumber informasi tak terbatas, dan hampir dapat menjawab semua pertanyaan kita. Dalam bidang bisnis, internet dapat mempermudah akses penjualan, promosi, pembelian, penawaran, trasaksi, autodidak, latihan berwirausaha, dan latihan menerapkan hasil membaca sumber bacaan berkonten Teknologi Tepat Guna (hasil observasi tahun 2017 
Pemanfaatan Internet untuk Penghidupan ... I Pawit M. Yusup, Neneng Komariah, Nurmaya Prahatmaja, Samson CMS

dan 2018).

\subsection{Fakta Lapangan}

Salah seorang informan (DN) yang pekerjaannya sebagai ibu rumah tangga, mengemukakan pengalamannya, "sebelum menggeluti usaha ini penghasilan dari kita jauh dari kata layak, tapi setelah kita menggeluti usaha ini kita bisa terbantu dari segi keuangan, dari usaha ini kita juga memiliki banyak kawan. tambahan pendapatan keluarga rata-rata sekitar lima juta rupiah per-bulan". Pernyataan tersebut mengandung makna tambahan penghasilan keluarga dan memperluas pergaulan. Meskipun tidak tetap jumlah penghasilannya tiap bulan, namun secara nominal dapat mencapai lima sampai delapan juta rupiah per-bulan (hasil wawancara 2017). DN yang hanya lulusan SMU dan sekarang sedang mengikuti pendidikan jenjang sarjana juga mengaku kurang paham memanfaatkan teknologi (gaptek). Namun setelah bergabung dalam kelompok usaha di sektor internet marketing, sekarang dapat mengoperasikan komputer dan berjualan melalui internet. Penghasilan DN pun semakin bertambah dan dapat membantu mencukupi kebutuhan keluarga. DN dan beberapa informan lain yang termasuk anggota kelompok usaha berbasis internet ini kini sudah nyaman dengan usaha dan pekerjaannya. Bekerja melalui internet dapat disesuaikan dengan kesibukan mengurus anak, bersosialisasi dengan tetangga, dan yang paling utama adalah menjadi dekat dengan keluarga. Jika dahulu mereka bekerja setiap hari dari pukul 07.00 - 21.00 WIB dengan penghasilan yang sedikit, sekarang mereka mendapatkan penghasilan yang lebih besar. "Memang tidak pasti, namun rata-rata yang sekarang lebih besar, cukup untuk kebutuhan sehari-hari", kata informan BA.

Berdasarkan pernyataan informan, dapat dikatakan bahwa bekerja melalui internet di pedesaan: (1) usaha tidak perlu di kota dan di kantor, asalkan tersedia jaringan internet dan satu komputer/laptop; (2) jika ada usaha, rizki melalui internet akan diperoleh; 3) ada persepsi orang desa yang bekerja di sawah dan ladang, bekerja dengan internet dianggap sedang bermain komputer/laptop; (4) hidup di desa tetapi berpenghasilan kota; (5) orang desa dapat bergaul secara luas dan mendunia; (6) internet sangat membantu dalam penyediaan informasi yang mendukung kemajuan kehidupan di desa. Hal tersebut dapat diketahui dari pola pencarian dan penggunaan informasi penghidupan yang mereka lakukan dengan internet melalui media sosial dan kemudian sumber orang, sementara media cetak tidak pernah digunakan (hasil wawancara 2017). Fakta lainnya adalah kelompok penduduk pedesaan yang tergolong prasejahtera atau miskin. Mereke memiliki keterbatasan dalam memanfaatkan internet serta keterbatasan dalam pengetahuan, keterampilan, keahlian, kebutuhan, dan pengalaman dalam menguasai sumber-sumber informasi penghidupan (Yusup, Kuswarno, \& Kurniasih, 2017).

\section{KESIMPULAN}

Berdasarkan pembahasan di atas dapat disimpulkan bahwa kelompok pemuda pedesaan yang memilih internet untuk usaha dan memenuhi penghidupan mereka, baik untuk jual beli barang, transaksi keuangan, dan komunikasi online. Dilihat dari aspek perilaku dan pengalaman, para pelaku usaha dapat terganggu jika terjadi gangguan jaringan internet. Mereka memanfaatkan internet untuk usaha pemasaran melalui media sosial, seperti Facebook dan Youtube, atau melalui jalan spamming. 


\section{DAFTAR PUSTAKA}

Abdi F \& Rachman MA. 2017. Information Seeking Behaviour of Woman In Slum Area In Kampung Poncol, South Jakarta, Indonesia (Perilaku Pencarian Informasi Wanita yang Tinggal di Daerah Kumuh di Kampung Poncol, Jakarta Selatan, Indonesia). Edulib 7 (1): 24.

Ardianto E \& Erdinaya LK. 2007. Komunikasi Massa Suatu Pengantar. Bandung: Simbiosa Rekatama Media.

Asosiasi Penyelenggara Jasa Internet Indonesia/APJII. 2016. Penetrasi dan Perilaku Pengguna Internet Indonesia. Survey tahun 2016. Infografis. Di https://inet.detik.com/cyberlife/d3339890/apjii-revisi-hasil-survei-internet-2016\#main (akses 7 Januari 2019).

Asosiasi Penyelenggara Jasa Internet Indonesia/APJII. 2018. Penetrasi Internet di Indonesia Capai 143 Juta Jiwa. Bulletin APJII Edisi 22.

Bailey KD. 1987. Methods of Social Research. Third Edition. New York: Free Press.

Febrian J. 2002. Menggunakan Internet. Bandung: Informatika.

Fisher KE. 2008. Theories of Information Behavior. ASIST Monograph Series. New Delhi, India: Ess Ess Publications.

Grešková M. 2007. Human-Agent Interaction from The Perspective of Information Behaviour and Usability. Information Research 12 (4).

Indo Telko. 2019. Ini Dia Profil Generasi Digital Indonesia. Di https://www.indotelko.com/kanal?c=id\&it=ini-dia-profil-generasi-digital-indonesia (akses 7 Januari 2019).

Irawan, Dasapta Erwin, et al. 2018. Era Baru Publikasi di Indonesia: Status Jurnal Open Access di Directory of Open Access Journal (DOAJ). Berkala Ilmu Perpustakaan dan Informasi, Vol.14, No. 2, Desember, DOI:10.22146/bip.32920.

Johnstone D, Bonner M, \& Tate M. 2004. Bringing Human Information Behaviour into Information Systems Research: An Application of Systems Modelling. Information Research $9(4): 191$.

Kamus Besar Bahasa Indonesia/KBBI. 2017. Internet. Di https://kbbi.web.id/internet (akses 7 Januari 2019).

Limberg L. 1999. Experiencing Information Seeking and Learning: A Study of The Interaction Between Two Phenomena. Information Research 5 (1).

Mulyana D. 2002. Metodologi Penelitian Kualitatif: Paradigma Baru Ilmu Komunikasi dan Ilmu Sosial Lainnya, Cetakan Kedua. Bandung: Remaja Rosdakarya.

Nextren.grid.id. 2018. Inilah Tren E-Commerce 2018 di Indonesia. Di http://nextren.grid.id/read/0124363/inilah-tren-e-commerce-2018-di-indonesia-menuruttoko-online-ini?page=all (akses 7 Januari 2019). 
Pemanfaatan Internet untuk Penghidupan ... I Pawit M. Yusup, Neneng Komariah, Nurmaya Prahatmaja, Samson CMS

Onlenpedia.com. 2017. Farida Retno: Kisah Ibu Rumah Tangga yang Sukses Berjualan Lewat Facebook.

Pratama AH. 2017. Perkembangan Pengguna Internet di Indonesia Tahun 2016 Terbesar di Dunia. Di https://id.techinasia.com/pertumbuhan-pengguna-internet-di-indonesia-tahun-2016 (akses 7 Januari 2019).

Pujiani I. 2014. Persiapan Indonesia dalam Menghadapi MEA (Masyarakat Ekonomi ASEAN). Di http://id.stie-stmy.ac.id/berita-165-persiapan-indonesia-dalam-menghadapi-meamasyarakat-ekonomi-asean.html (akses 7 Januari 2019).

Reddick R \& King E. 1996. Internet untuk Wartawan: Internet untuk Semua Orang. Jakarta: Yayasan Obor Indonesia.

Risbang Dikti. 2019. Di https://risbang.ristekdikti.go.id/publikasi/berita-media/2019-jurnalilmiah-indonesia-tertinggi-di-asean/ (akses 6 Januari 2019).

Savolainen R. 2007. Information Behavior and Information Practice: Reviewing the "Umbrella Concepts" of Information-Seeking Studies. The Library Quarterly 77 (2), 109 - 27.

Schutz A. 1967. The Phenomenology of the Social World. Northwestern University Studies in Phenomenology \& Existential Philosophy. Illinois: Northwestern University Press.

Thivant E. 2005. Information Seeking and Use Behaviour of Economists and Business Analysts. Information Research, 10 (4):234.

Wilson TD. 2000. Recent Trends in User Studies: Action Research and Qualitative Methods. Information Research, 5 (3).

Wilson TD. 2002. Alfred Schutz, Phenomenology and Research Methodology for Information Behaviour Research. A Paper Deliveredat ISIC4 - Fourth International Conference on Information Seeking in Context, Universidade Lusiada, Lisbon, Portugal, September 11 to 13.

Yusup PM, Kuswarno E, \& Kurniasih N. 2017. Aspek Keterbatasan Akses Informasi Penghidupan Orang Miskin Pedesaan (Limitedness Aspects to Access Livelihood Information for The Rural Poor). Masyarakat, Kebudayaan, dan Politik, Vol.30 (1), 34 - 47.

Yusup, PM \& Komariah N. 2014. Health Information Seeking and Use Among Rural Poor Families In West Java, Indonesia. Brazilian Journal of Information Science: Research Trends $8(1 / 2): 1-10$. 